\title{
A COMPARATIVE STUDY OF CREATION OF SELF-BRAND CONNECTION AMONGST WELL-LIKED, NEW, AND UNFAVORABLE BRANDS
}

\author{
JOURNAL OF BUSINESS RESEARCH, 2018, VOLUME 92
}

\author{
Teck Ming Tan ${ }^{1}$ \\ Assistant Professor of Marketing \\ Oulu Business School, University of Oulu \\ Pentti Kaiteran katu 1, 90014 Oulu, Finland. \\ Phone: +358449235960 \\ E-mail: teckming.tan@oulu.fi \\ Jari Salo \\ Professor of Marketing \\ Department of Economics and Management, University of Helsinki \\ P.O. Box 27 (Latokartanonkaari 5) 00014 University of Helsinki, Finland. \\ Phone: +358294158084 \\ E-mail: jari.salo@helsinki.fi \\ Jouni Juntunen \\ Associate Professor of Marketing (Senior Research Fellow) \\ Oulu Business School, University of Oulu \\ Pentti Kaiteran katu 1, 90014 Oulu, Finland. \\ Phone: +358294482589 \\ E-mail: jouni.juntunen@oulu.fi \\ Ashish Kumar \\ Assistant Professor of Marketing \\ Aalto University School of Business \\ Arkadia, Lapuankatu 2, 00100, Finland. \\ Phone: +358 504311 813; E-mail: ashish.kumar@ aalto.fi
}

${ }^{1}$ Teck Ming Tan is the corresponding author

\section{Acknowledgment}

This paper is based on a part of the first author's dissertation, under the guidance of the second and third authors. The authors gratefully acknowledge the financial support from a four-year funded position as part of the University of Oulu Graduate School doctoral programme awarded to Teck Ming. The authors would like to thank Jari Juga, Mari Juntunen, Waqar Nadeem, Timo Pohjosenperä, and Robert Wilken for their invaluable comments and feedback on this article. Finally, the authors are thankful to Anders Gustafsson, Margaret Kathleen Hogg, and reviewers for their constructive comments in the review process. 


\title{
A COMPARATIVE STUDY OF CREATION OF SELF-BRAND CONNECTION AMONGST WELL-LIKED, NEW, AND UNFAVORABLE BRANDS
}

\begin{abstract}
Brand managers are wary of consumers who are either unaware of new brands or have an unfavorable attitude toward their brands. In this study, we investigate the creation of a self-brand connection with new and unfavorable brands in comparison to well-liked brands. Our empirical study reveals that consumers could form a self-brand connection with new and unfavorable brands when the brand serves as a self-presentational strategy-self-presentation by brand. In particular, first, we find that brand attitude predicts self-brand connection positively and significantly for a well-liked brand, but not for a new brand, and second, when consumers hold favorable (unfavorable) attitudes toward a familiar brand, the self-brand connection can exist (be diluted). Thus, the self-brand connection can vary depending upon consumers' favorability toward the brand. The current study suggests that one-on-one marketing, including customization and personalization, is relevant to new and unfavorable brands.
\end{abstract}

Keywords - self-brand connection; brand attitude; brand familiarity; self-presentation; brand knowledge; structural equation modeling 


\section{Introduction}

A self-brand connection serves as an important element of the brand relationship as it refers to the way consumers establish a sense of oneness with a brand (Park, MacInnis, Priester, Eisingerich, \& Iacobucci, 2010). Until recently, research on the self-brand connection has centered on well-liked brands (Dennis, Papagiannidis, Alamanos, \& Bourlakis, 2016; Merchant \& Rose, 2013) and unfavorable brands (Ferraro, Kirmani, \& Matherly, 2013). There is limited research on the linkage between the creation of self-brand connection and consumers' favorability toward the brand. To this end, Chatzipanagiotou, Veloutsou, and Christodoulides (2016) called for research focusing on a comparison between the well-liked and unfavorable brands to extend an understanding of a holistic brand relationship. In this study, we explore such a brand relationship in the context of the self-brand connection among well-liked, new, and unfavorable brands using theories from customer-based brand equity and self-presentation by brand (SPB).

Customer-based brand equity (CBBE) is defined as "the differential effect of brand knowledge on consumer response to the marketing of the brand" (Keller, 1993, p. 8). Research on $\mathrm{CBBE}$ is essential in order to capture the self-brand connection, as consumer attitude toward the favorability, strength, and uniqueness of the brand moderates the creation of self-brand connection. Such favorable (unfavorable) consumer attitudes, in turn, establish a sense of oneness (discord) with a brand that is positively (negatively) linked to building the brand relationship (Escalas, 2004; Park et al., 2010). Given the importance of CBBE in understanding the brand relationship with the consumer, Keller (2016) called for an investigation of consumers' brand association with newly introduced brands with which consumers have little or no interest. 
Such an investigation will provide a comparative understanding of the brand relationship among a well-liked brand, an unfavorable brand, and a new brand.

A well-liked brand is defined as a brand that consumers have a positive feeling about or that they have had a positive experience with (Keller, 1993). An unfavorable brand ${ }^{l}$ is viewed as a brand that consumers have a negative attitude toward, which results from dissatisfaction or fairness violations (Grégoire \& Fisher, 2008). A new brand ${ }^{2}$ relates to a brand that consumers are not familiar with and thus have little knowledge with which to form either a favorable or an unfavorable association (Keller, 1993). As consumers have a certain level of familiarity and a favorable attitude toward a well-liked brand, then they become the drivers of the self-brand connection (Schmitt, 2012). However, the development of self-brand connection might be nonexistent in the case of a new brand to which consumers have limited exposure (Park et al., 2010). If a brand is viewed unfavorably, consumers associate the brand with their negative attitude, making it irrelevant to try to develop a self-brand connection. In addition, a lovebecomes-hate effect may exist when consumers start forming a negative attitude toward a familiar brand (Grégoire, Tripp, \& Legoux, 2009), and this effect may dilute the self-brand connection. For these reasons, it is essential to investigate the predictive value of brand attitude and brand familiarity regarding the self-brand connection with well-liked, new, and unfavorable brands.

\footnotetext{
${ }^{1}$ An illustrative scenario of a brand relationship in the context of an unfavorable brand is as follows: David is a fashion designer. He holds an unfavorable attitude toward Microsoft products as his old Windows phone's screen often turned black after system updates, which caused him to be unable to use the phone several times during an emergency. However, David starts connecting himself with Microsoft brand after knowing the company has introduced Surface Studio and Surface Pro, which closely relate to his profession. He believes that using the Microsoft products could present him effectively to others as a contemporary designer.

${ }^{2}$ An illustrative scenario of a brand relationship in the context of a new brand is as follows: You and your friend have never heard about the Dsquared ${ }^{2}$ brand. After she tried on a few pairs of Dsquared ${ }^{2}$ mid-rise jeans at the Woodbury Common Premium Outlets, she starts connecting to Dsquared ${ }^{2}$ as she looked great with the jeans on and perceived the brand could help her to give a positive impression of herself when in public.
} 
SPB has been an important driver of self-brand connection, in addition to brand attitude and brand familiarity (Tan, Salo, Juntunen, \& Kumar, 2017). The critical role of SPB is due to the fact that when consumers perceive a brand as an identity signal, the brand functions as a means of maintaining a positive impression in front of others and such symbolic benefits allow consumers to connect themselves with the brand. The literature on the relationship between SPB and self-brand connection is very scant. Therefore, in this study, we address the following research questions: How do well-liked, new, and unfavorable brands moderate the relationships of brand attitude, brand familiarity, SPB, and self-brand connection?

To address our research questions, we develop a conceptual framework for moderating the effects of well-liked, new, and unfavorable brands on brand attitude, brand familiarity, SPB, and self-brand connection. We empirically test our framework using clothing and consumer electronics product brands. Our findings reveal that brand attitude, brand familiarity, and SPB are relatively vital to the creation of self-brand connection for well-liked brands. However, if the brand is viewed unfavorably or if it is new, only SPB is found to have a positive effect on the self-brand connection. The current study contributes to the existing literature in several ways. First, we address the calls of Chatzipanagiotou et al. (2016) and Keller (2016) to extend research on the creation of self-brand connection by comparing new, unfavorable, and well-liked brands. Second, we integrated the consumer psychology model of brands (Schmitt, 2012) with SPB by testing its predictive ability for the self-brand connection. In the next section, we review the relevant literature used in developing our conceptual framework, followed by presenting two studies that test the hypotheses, and finally conclude with the current research's contributions, managerial implications, limitations, and suggestions for future research. 


\section{Literature review}

\subsection{The consumer psychology model of brands}

We draw from the literature on the consumer psychology model of brands (CPMB; Schmitt, 2012) to build our framework. The CPMB provides a theoretical underpinning for explaining a comprehensive framework for the psychology of brands. This framework focuses on the different levels of consumers' psychological engagement with brands and the underlying processes that drive consumers to relate themselves to the brand. We adopted the CPMB as it discusses the constructs of our framework within the level of consumer engagement and the underlying processes, which include self-brand connection, brand attitude, and brand familiarity/awareness. It also highlights the importance of brand participation for a new brand and the possibility of an adverse brand relationship (i.e., unfavorable brand perception). Further, the CPMB categories self-brand connection (a component of brand attachment; Park et al., 2010) as a self-centered engagement construct, which provides a direction for this study that positions the self-brand connection as a dependent variable that is predicted by object-centered engagement constructs, such as brand attitude and brand familiarity.

Although the model has provided extensive coverage of how consumers relate themselves to a brand to signify their identity, it does not give a detailed discussion of how the signifying process could be related to self-presentation motivation, despite previous studies showing that self-brand connection involves the way in which consumers utilize brands as part of their self-presentational strategy (Escalas \& Bettman, 2003; 2009). Besides this, the model does not provide a rich understanding of how consumers perceive a new brand or an unfavorable brand in a brand relationship, which is related to a differing level of favorability, and this might 
have a different process to that found for a well-liked brand (Chatzipanagiotou et al., 2016; Keller, 2016). Therefore, our study fills such gaps in the literature.

\subsection{Brand relationships: Brand attitude, brand familiarity, SPB}

Brand attitude refers to the consumer's overall evaluation of a brand that ranges from positive to negative valence (Albert, Ambroiseb, \& Valette-Florence, 2017). It consists of all the relevant elements that are presented in the consumer's mind, such as experiences with the brand, packaging, advertisements, brand attributes, and the benefits of a brand (Langaro, Rita, \& de Fátima Salgueiro, 2018). Brand familiarity is defined as the level of a consumer's experience and information about a brand (Gretry, Horváth, Belei, \& van Riel, 2017). Drawing from the associative network memory model (Keller, 1993), brand familiarity represents a cognitive structure in the consumer's memory, which allows the consumer to differentiate a familiar brand from an unfamiliar brand and thus pay more attention to the familiar brand (Boronczyk, Rumpf, \& Breuer, 2018).

SPB refers to how consumers perceive how others view them while presenting themselves with a brand, which in turn relates to impression motivation and impression construction (Leary \& Kowalski, 1990). SPB is distinct from self-brand connection in three ways. First, self-brand connection is influenced by whether the brand is associated with an in-group or an out-group, which results in self-brand linkage or self-brand separation that involve complex feelings about the brand, and thus they relate to the subjective sense of brand evaluation (Escalas \& Bettman, 2003; Park et al., 2010). SPB is associated with the objective sense of judgment that evaluates whether a brand has efficiently presented the consumer's self to others. Second, selfbrand connection is considered a long-term construct as establishing a sense of oneness with a 
brand is mostly time-dependent (Escalas \& Bettman, 2009). SPB is not necessarily time dependent as it evaluates whether the brand serves as a means of self-presentational strategy and it can be formed instantly using a self-customization procedure (Tan et al., 2017). Third, selfbrand connection is an attachment-based brand relationship (Park et al., 2010), which explains the bond between a brand and the consumer. Contrarily, SPB emphasizes the signifying ability of a brand (Schmitt, 2012) and thus is related to the fit of the brand's personality and the consumer's self (MacInnis \& Folkes, 2017).

\subsection{Hypothesis development}

We add to the CPMB (Schmitt, 2012) by proposing that SPB results from self-centered engagement with brands. It engages the consumer with a brand by involving signifying processes. Previous studies show that individuals are more willing to connect with a brand that they perceive to offer benefits derived from self-presentation (Escalas, 2004; Schmitt, 2012). Scholars have found that the consumer's need for self-presentation is related to positive word of mouth for a brand, which in turn is connected to the consumer's self-concept (Eelen, Özturan, \& Verlegh, 2017). Hence, we suggest that a consumer who is engaged in SPB is expected to hold a self-brand connection.

H1. SPB is positively related to self-brand connection.

Escalas (2004) states that self-brand connection is positively related to brand attitude; she argues that brand attitude is an outcome of self-brand connection as consumers may form favorable attitudes toward brands with which they do not hold a self-brand connection. However, 
in the review of the CPMB, brand attitude is considered the innermost layer that is derived from object-centered and functionally-driven engagement; that is, the consumers' perceive benefits to be gained and thus hold a favorable attitude toward the brand. Schmitt (2012) also states that consumers are likely to form some level of favor or liking before connecting themselves with the brand. Thus, brand attitude could be an antecedent of self-brand connection.

H2. Brand attitude is positively related to self-brand connection.

Based on expectancy-value theory, consumers should have a unique and strong association with the well-liked brand as it meets the consumers' expectations, where consumers have sufficient knowledge and experience about utilizing the brand so that the brand can serve as a value-expressive function (Keller, 1993). Thus, consumers form a generally positive attitude toward the well-liked brand due to their evaluations of the brand's multi-attributes and benefits (Langaro et al., 2018). Moreover, consumers tend to judge the well-liked brand by using extrinsic cues rather than a thoughtful decision-making process as they lack the motivation to reassess the well-liked brand that they already know (Olson \& Jacoby, 1972). Based on this notion, we argue that brand attitude that captures consumers' overall evaluations of the wellliked brand should contribute to a stronger effect on self-brand connection than on SPB, which relates to the assessment of the brand's symbolic benefit.

H3. Brand attitude has a stronger positive effect on self-brand connection than SPB for a well-liked brand. 
When consumers evaluate a new brand, they do not have much prior knowledge and experience about the brand compared to a well-liked brand (Lam, Ahearne, Mullins, Hayati, \& Schillewaert, 2013). Thus, consumers have insufficient knowledge to form an overall evaluation of the brand, and they start learning about how the new brand could be congruently associated with their existing knowledge (Keller, 1993). Typically, knowledge about self-presentation or impression management plays a significant role in interpersonal behavior, whether in an offline context (Leary \& Kowalski, 1990) or in an online context (Ellison, Heino, \& Gibbs, 2006). Goffman (1959) states that people consciously, and also subconsciously, engage in their selfpresentation, and they tend to project their desired images onto cues for physical appearance (Schneider, Hastorf, \& Ellsworth, 1979), clothing and jewelry (O’Guinn, Tanner, \& Maeng, 2015), and conspicuous and inconspicuous consumption (Berger \& Ward, 2010). For these reasons, we suggest that SPB is more relevant than brand attitude in the evaluation of a new brand as SPB enables consumers to identify the benefits gained from the brand (Keller, 1993) and to visualize how the new brand could be beneficial as a personal identity signal; thus, SPB connects them with the brand (Schmitt, 2012).

H4. SPB has a stronger positive effect on self-brand connection than brand attitude for a new brand.

Consumers become familiar with a brand when they link the brand with a large number of cues that hold strong memories about the brand, which includes both favorable and unfavorable information about the brand (Keller, 1993). For this reason, brand familiarity does not necessarily contribute to a positive outcome for a well-liked brand; it might restrict a brand 
from being revitalized as consumer memory is extremely durable (Loftus \& Loftus, 1980). One possible solution is to rebuild consumers' brand knowledge by associating them with the brand as an identity signal that seems personally relevant to them (Schmitt, 2012), rather than centering on brand familiarity (Keller, 2003). Mühlbacher, Raies, Grohs, and Koll (2016) advised focusing on the brand's perceived benefits as this contributes to self-brand connection. Thus, we hypothesize the following:

H5. SPB has a stronger positive effect on self-brand connection than brand familiarity for a well-liked brand.

Koll and von Wallpach (2014) argue that brand familiarity is positively associated with consumers' response toward the marketing brand. However, we contend that this is not necessarily the case as consumers might be familiar with an unfavorable brand to which they used to be a loyal customer, yet they have switched to another brand due to dissatisfaction, fairness violation, or brand betrayal (Grégoire \& Fisher, 2008). Our explanation is in line with the work of Grégoire et al. (2009) who explain that consumers may have processed a lovebecomes-hate effect when they hold an unfavorable attitude toward a formerly well-liked brand - consumers have disassociated themselves from the brand as it now fails to meet their expectations (Ashley, Gillespie, \& Noble, 2016). These arguments lead us to the following hypothesis:

H6. Brand familiarity is negatively related to self-brand connection for an unfavorable brand. 
We did not include unfavorable brands as a moderating variable in the relationship between brand attitude and self-brand connection as when consumers hold a negative brand attitude this restricts them from establishing the self-brand connection (Park et al., 2010). Also, a new brand is not treated as a moderating variable in the relationship between brand familiarity and self-brand connection as when consumers are unfamiliar with a brand they are unable to provide conscious perception of forming the self-brand connection (Batra, Ahuvia, \& Bagozzi, 2012). Conversely, new and unfavorable brands are treated as moderating variables in the relationship between SPB and self-brand connection as a previous study found that SPB can be formed instantly by providing consumers with psychological benefits (Tan et al., 2017), thereby developing a self-brand connection. For these reasons, we conducted two different studies to test the conceptual framework. Study 1 served to address H1, H2, H3, and H4 by comparing wellliked and new brands, whereas Study 2 served to answer H1, H5, and H6 by comparing wellliked and unfavorable brands.

\section{Methodology}

We used Qualtrics to design a self-administrated online questionnaire as it randomly assigns respondents to a different condition and allows them to insert a brand name input, which appears throughout the questionnaire. Clothing and consumer electronics products were selected because of their relation to self-presentation (Eastman, Goldsmith, \& Flynn, 1999). We used a non-probability convenience sampling method as the conceptual framework is derived from theoretical background (Calder, Philips, \& Tybout, 1982).

We first performed confirmatory factor analysis to identify a measurement model by confirming the relationship between the observed variables and latent variables, which enabled a 
comprehensive assessment of construct validity, including convergent and discriminant validity.

Next, comparing structural models with different groups was conducted to test the hypotheses.

\section{Study 1}

Two hundred seventy-nine respondents were recruited from a large public university.

They were asked to respond about either their well-liked brands or a new brand. In the well-liked brand condition, respondents were asked to list a fashion brand with which they have had a positive feeling and a positive experience. In the new brand condition, respondents were given a fictitious Zeemiata clothing brand. We included a Zeemiata logo and a brief description to present the basic concepts of the brand to them (see Appendix A).

Respondents then were asked to respond items of brand attitude (Spassova \& Lee, 2013; "bad versus good," "unpleasant versus pleasant," "unfavorable versus favorable"; ranging from -3 to 3), SPB (Tan et al., 2017; "I believe that X could help me to present myself effectively in front of my friends," "I believe that X could help me to present myself effectively in front of strangers," "I believe that X could help me to give a positive impression of myself in public"; ranging from 1 = strongly disagree to 7 = strongly agree), self-brand connection (Park et al., 2010; "To what extent is X could reflect part of you and who you are?" "To what extent do you feel personally connected to X?" ranging from $1=$ strongly disagree to $7=$ strongly agree), demographic questions, and manipulation check questions (brand familiarity questions) adapted from Kent and Allen (1994; "unfamiliar versus familiar," "inexperienced versus experienced," "not knowledgeable versus knowledgeable"; ranging from -3 to $3 ; \alpha=.95$ ).

We excluded two respondents as they did not insert a brand name and hence the survey was incomplete. The results revealed the successful manipulation of brand condition $\left(\mathrm{M}_{\text {well-liked }}\right.$ 
brands $=2.17$ vs. $\left.\mathrm{M}_{\text {new brand }}=-2.19 ; t(275)=41.51, p<.001\right)$. Table 1 presents the profile of survey respondents.

[Table 1 about here]

\subsection{A comparison of mean scores amongst well-liked and new brands}

The participants evaluated well-liked brands more favorably $\left(\mathrm{M}_{\text {well-liked }}=2.06 \mathrm{vs} . \mathrm{M}_{\text {new }}=\right.$ $0.81, t=12.44, p<.001)$ and had significantly higher levels of SPB $\left(\mathrm{M}_{\text {well-liked }}=5.14 \mathrm{vs.} \mathrm{M}_{\text {new }}=\right.$ $3.28, t=11.44, p<.001)$ than the respective responses to the new brand. They also felt more connected to the well-liked brands than the new brand $\left(\mathrm{M}_{\mathrm{well}-\mathrm{liked}}=3.89\right.$ vs. $\mathrm{M}_{\text {new }}=2.69, t=7.49$, $p<.001)$. Such findings further confirm the manipulation of the brand condition by presenting the mean score differences of the constructs that were included in this research. However, the significant differences in the mean scores do not explain the predictive ability of exogenous variables on the endogenous variable. Thus, structural equation modeling (SEM) was performed to compare the predictive ability of brand attitude and SPB regarding the self-brand connection amongst the well-liked and new brands.

\subsection{The results of the measurement model}

The results reveal that our measurement model fits the data well $\left(\chi^{2} /\right.$ d.f. $=2.322$, root mean square error of approximation $[\mathrm{RMSEA}]=.069$, non-normed fit index $[\mathrm{NNFI}]=.978$, comparative fit index $[\mathrm{CFI}]=.987$, and standardized root mean square residual $[\mathrm{SRMR}]=.030$ ). Table 2 presents our measurement structures, showing they have sufficient reliability and validity: All the Cronbach's alpha and composite reliability exceeded the value of .80, whereas 
the average variance extracted (AVE) exceeded .70. For the discriminant validity, the results across two studies support the square root of AVE, exceeding the correlations between all pairs of constructs (see Table 3). Thus, no validity concern is found (Hair, Black, Babin, \& Anderson, 2010).

[Table 2 and Table 3 about here]

\subsection{The results of structural models}

Figure 1 provides the complete results of three structural models, which suggests that Models 1 and 2 fit the data well, as recommended by Hair et al. (2010). Referring to Model 3, the RMSEA exceeded .08, as suggested by Hair et al. (2010). The models show an adequate level of NNFI and CFI, which are above 90 (Jaccard \& Wan, 1996), and SRMR values are below .08, as proposed by Hair et al. (2010). Hence, Model 3 fulfilled most of the fit indices as suggested and the models could be accepted (Juntunen, Juntunen, \& Autere, 2013). The details of the factor loadings and error variances for each structural model are listed in Appendix B.

[Figure 1 about here]

The results of the basic model confirm that SPB is positively related to self-brand connection (Model 1: $\beta=.50, t=5.70, p<.001$ ), which supports H1. Model 1 shows that brand attitude $(\beta=.25, t=2.95, p=.003)$ positively and significantly predicted self-brand connection, providing support for $\mathrm{H} 2$. When respondents were asked to evaluate well-liked brands, SPB (Model 2: $\beta=.31, t=2.90, p=.004$ ) and brand attitude (Model 2: $\beta=.35, t=3.29, p<.001$ ) 
positively and significantly predicted self-brand connection. On the basis of a chi-square difference test (as shown in Table 4), brand attitude has a stronger positive effect on self-brand connection than SPB (Model 2: $\Delta \beta=.04, \Delta \chi^{2}=10.04, \Delta d . f .=1, p=.002$ ), which supports H3. In contrast, when respondents were asked to evaluate a new brand, the relationship between brand attitude and self-brand connection become insignificant (Model 3: $\beta=.08, t=0.68, p$ $=.504$ ), whereas SPB predicted self-brand connection positively and significantly (Model 3: $\beta$ $=.61, t=5.00, p<.001)$. Therefore, $\mathrm{H} 4$ is supported.

[Table 4 about here]

\subsection{Discussions}

Our findings are in line with the CPMB (Schmitt, 2012), which supports the idea that the brand constructs concerning self-centered engagement (i.e., SPB) and object-centered engagement (i.e., brand attitude) are expected to have positive effects on the self-brand connection. When consumers evaluate a well-liked brand, they tend to judge the brand's overall multi-attributes (i.e., their brand attitude) that exist in their current brand knowledge in order to establish the self-brand connection. However, when consumers evaluate a new brand, they do not have prior knowledge or experience of the brand. They tend to identify how the new brand could be associated with their existing brand knowledge. Specifically, consumers are sensitive to the symbolic benefits that can be gained that relate to self-presentation (Berger \& Ward, 2010; Ellison et al., 2006; Goffman, 1959; Leary \& Kowalski, 1990; O'Guinn et al., 2015). Thus, the new brand that consumers perceive as an identity signal (i.e., SPB) enables them to maintain a positive impression in the social world, and this then drives them to self-brand connection. Our 
findings also explain the effect of brand attitude on the self-brand connection that was ruled out by Escalas (2004), suggesting that the existence of brand attitude entails a positive self-brand connection to the well-liked clothing brand that is closely related to the consumer's self-concept.

\section{Study 2}

Four hundred respondents were recruited through Amazon Mechanical Turk to respond about either well-liked or unfavorable brands of consumer electronics products. In the well-liked brand condition, respondents were asked to list an electronics brand with which they have had a positive feeling and they were satisfied with it. In the unfavorable brand condition, respondents were asked to list an electronics brand that they used before but had stopped using due to dissatisfaction with the brand. Respondents then were asked to respond to items of brand familiarity, SPB, self-brand connection, demographic questions, and manipulation check questions (brand attitude questions; $\alpha=.96$ ).

Seven respondents were excluded as they did not insert a brand name and hence the survey was incomplete. The final set of usable responses consisted of 393 responses. The results revealed successful manipulations of brand condition $\left(\mathrm{M}_{\text {well-liked brands }}=2.87 \mathrm{vs} . \mathrm{M}_{\text {unfavorable brands }}=\right.$ $-0.14 ; t(391)=22.55, p<.001)$. The top ten favorable electronics brands that were listed by participants were Apple, Samsung, Sony, LG, Hewlett-Packard, Dell, Toshiba, Motorola, Acer, and Canon, which accounted for $84 \%$ of the listed brands, whereas the top ten unfavorable brands that were listed by participants were Sony, Apple, Samsung, Dell, Canon, LG, Casio, Hewlett-Packard, Panasonic, and Lenovo, which accounted for $61 \%$ of the listed brands. 


\subsection{A comparison of mean scores amongst well-liked and unfavorable brands}

The participants had significantly higher levels of SPB $\left(\mathrm{M}_{\text {well-liked }}=5.09 \mathrm{vs} . \mathrm{M}_{\text {unfavorable }}=\right.$ $3.49, t=9.89, p<.001)$ and were more connected $\left(\mathrm{M}_{\text {well-liked }}=4.56 \mathrm{vs} . \mathrm{M}_{\text {unfavorable }}=3.09, t=\right.$ $8.53, p<.001)$ to the well-liked brands than the unfavorable brands. They were also reported to have significantly higher levels of familiarity $\left(\mathrm{M}_{\text {well-liked }}=2.30 \mathrm{vs}\right.$. $\mathrm{M}_{\text {unfavorable }}=1.67, t=6.28, p$ $<.001)$ with the well-liked brands than with the unfavorable brands. Next, we performed SEM to examine the predictive ability of brand familiarity and SPB on the self-brand connection amongst the well-liked and unfavorable brands.

\subsection{The results of the measurement model}

Table 2 and Table 3 reveal that our measurement model fits the data well $\left(\chi^{2} / d . f .=2.404\right.$, RMSEA $=.060, \mathrm{NNFI}=.986, \mathrm{CFI}=.992$, and SRMR $=.024)$ and show sufficient reliability and validity. Thus, no validity concern is found (Hair et al., 2010).

\subsection{The results of structural models}

Figure 2 suggests that Models 4, 5, and 6 fit the data well, as recommended by Juntunen et al. (2013). The results of the basic model confirmed that SPB is positively related to self-brand connection (Model 4: $\beta=.71, t=15.90, p<.001$ ), which is in line with Study 1 , and thus H1 is further supported. We conducted a chi-square difference test with an unconstrained model and a constrained model in order to investigate whether when consumers evaluate well-liked brands, SPB has a stronger positive effect on self-brand connection than brand familiarity. Although there is no significant difference in the chi-square after constraining the model for well-liked brands (Model 5: $\Delta \beta=.35 ; \Delta \chi 2=0.55, \Delta d . f .=1, p=.457$ ), the result shows .35 difference in the 
comparison of parameter estimates. Thus, H5 is supported. The result of the basic model also shows that brand familiarity is not able to predict self-brand connection (Model 4: $\beta=.01, t=$ $0.12, p=.902)$. However, brand familiarity predicted self-brand connection positively and significantly in the evaluation of well-liked brands (Model 5: $\beta=.20, t=2.91, p=.004$ ), and the relationship between brand familiarity and self-brand connection became significantly negative when respondents were asked to evaluate the unfavorable brands (Model 6: $\beta=-.13, t=-2.36, p$ $=.018$ ), providing support for H6. Remarkably, SPB predicted self-brand connection positively and significantly in the evaluation of both well-liked brands (Model 5: $\beta=.55, t=7.46, p<.001$ ) and unfavorable brands (Model 6: $\beta=.72, t=11.99, p<.001$ ).

[Figure 2 about here]

\subsection{Discussions}

Our findings embrace the fact that the development of self-brand connection involves a benefit or economic exchange (Swaminathan \& Dommer, 2012). The brand should be meaningful to consumers and perceived to offer symbolic benefit in order to build consumers' brand knowledge (e.g., SPB), rather than focusing on familiarity, which captures the general recognition level about the brand (Keller, 2003; Mühlbacher et al., 2016). In the basic model, we found that brand familiarity does not drive self-brand connection, a finding that is in line with the work of Ferraro et al. (2013). However, brand familiarity is positively (negatively) related to self-brand connection if the brand is well-liked (unfavored). We further followed up the analysis of structural models by excluding any non-significant effects; the results showed less than .06 differences in parameter estimates when comparing the hypothesized and cleaned models. To 
conclude, the results of the structural models revealed that all the parameter estimates were found to support the hypotheses and there was no evidence of confounding effects (Hair et al., 2010).

\section{Conclusions}

\subsection{Theoretical implications}

This research provides a two-fold contribution. First, our study addresses the importance of examining moderating effects by comparing structural models with different groups as the consumers' perceptions and preferences can be varied, depending upon their favorability toward a brand (Chatzipanagiotou et al., 2016; Keller, 2016). In the current study, consumers are considered to have a favorable association with the well-liked brand, a negative relationship with the unfavorable brand, and limited knowledge of the new brand. The different level of favorability resulted in a different evaluative judgment for the self-brand connection. Our findings show that SPB is relatively vital to the new and unfavorable brands compared to the well-liked brands when considering the creation of self-brand connection. One possible explanation for this is that consumers start connecting with a brand that is based on an exchange norm, rather than a communal norm. Consumers are unlikely to view an attribute of a new brand or an unfavorable brand as good or bad if the attribute is not essential to them. They expect to gain benefits, such as self-presentational benefits, from the brand when they interact with the new and unfavorable brands that could be acknowledged instantly by signifying their identity. On the other hand, consumers should have favorable, unique, and strong associations with a well-liked brand as the brand has satisfied their needs (Keller, 1993). Thus, when consumers 
evaluate a well-liked brand, the overall positive attitude toward the brand is more relevant than $\mathrm{SPB}$, and brand familiarity could drive self-brand connection.

Second, the current research contributes to the self-brand connection literature that articulates the consumer's self-construal through a brand's ability to serve as a means of selfpresentational strategy (Escalas \& Bettman, 2009, Park et al., 2010). Specifically, we contribute to the CPMB (Schmitt, 2012) by integrating brand literature with self-presentation literature by explaining identity signals from the consumers' self-centered engagement. SPB exists when the brand seems personally relevant to the consumers via a signifying process, thus it relates the brand as an identity signal (Schmitt, 2012) from which consumers gain symbolic benefit through managing their positive impressions. Our study further shows that self-presentation acts as an important informational cue for a brand as it predicts a stronger effect on self-brand connection than brand attitude and brand familiarity when evaluating a new brand or an unfavorable brand.

Notably, our study demonstrates the dilution effect of brand familiarity on the self-brand connection that occurs among unfavorable brands. The love-becomes-hate effect (Grégoire et al., 2009) explains this finding; consumers may form an extremely durable unfavorable memory about a brand through dissatisfaction, fairness violation, or brand betrayal (Grégoire \& Fisher, 2008; Loftus \& Loftus, 1980). Thus, brand familiarity weakens the self-brand connection in the evaluation of unfavorable brands as it does not serve as a means of brand recovery or offer any benefits, a finding that taps into the negative impact of brand familiarity.

\subsection{Managerial implications}

The current research presents a branding strategy for the new and unfavorable brand by considering the SPB. Although brand personality (Aaker, 1997) is undeniably vital in branding 
strategy (MacInnis \& Folkes, 2017), measuring SPB could be more efficient in brand management as it refers to the outcome of brand self-congruity. Koll and von Wallpach (2014) suggest that brand managers should focus on creating a favorable brand association for a positive brand response, rather than considering the congruence of actual consumer brand association and management-intended brand association. Thus, managers could consider how a new and an unfavorable brand could serve as a means of self-presentational strategy. Managers could implement one-on-one marketing, such as customization and personalization in their branding activities. Managers could develop a mobile application or provide an onsite service counter that allows consumers to customize their clothing style or a gadgets' front cover, or to have their name on products.

Besides this, most consumers nowadays leave their behavioral data on search engines and social media sites. Thus, brand managers may need to reconsider brand familiarity's role in enhancing advertisement memorability among those consumers who have an unfavorable attitude toward their brands due to dissatisfaction. Regarding celebrity endorsement, consumers might not agree with the poor personal lifestyle of certain celebrities, thus consumers form an unfavorable attitude toward them and tend to leave dislikes or negative comments in response to the celebrity's online posts. With the advanced technology of today (such as the analysis of social media data), brand managers could personalize their celebrity endorsement based on the consumers' favorability toward a celebrity.

\subsection{Limitations and future research}

Several of the study limitations can be seen as directions for future research. First, this study only focuses on one dependent variable, self-brand connection, without exploring the 
predictive ability of SPB for other brand outcomes. A future study could be conducted to examine the impact of SPB on other variables, such as brand loyalty, brand passion, and positive word-of-mouth. The second limitation is that there is no comparison between the symbolic and functional benefits of brands. A future study could include utilitarian attributes and perceived quality as part of the structural model to compare the predictive ability of SPB on the self-brand connection. Moreover, as the product stimuli are related to clothing and consumer electronics products brands, our findings might be more relevant to publicly consumed products rather than privately consumed products. Lastly, future research on vector autoregressive modeling that incorporates SPB, attitudinal data, and a firm's market performance is needed to identify how SPB can be used as a part of metrics-based quantitative research. 


\section{References}

Aaker, J. L. (1997). Dimensions of brand personality. Journal of Marketing Research, 34(3), 347-356.

Albert, N., Ambroise, L., \& Valette-Florence, P. (2017). Consumer, brand, celebrity: Which congruency produces effective celebrity endorsements? Journal of Business Research, 81, 96-106.

Ashley, C., Gillespie, E. A. \& Noble, S. M. (2016). The effect of loyalty program fees on program perceptions and engagement, Journal of Business Research, 69(2), 964-973.

Batra, R., Ahuvia, A., \& Bagozzi, R. P. (2012). Brand love. Journal of Marketing, 76(2), 1-16.

Berger, J. \& Ward, M. (2010). Subtle signals of inconspicuous consumption. Journal of Consumer Research, 37(4), 555-569.

Boronczyk, F., Rumpf, C., \& Breuer, C. (2018). Determinants of viewer attention in concurrent event sponsorship. International Journal of Sports Marketing and Sponsorship, 19(1), 11-24.

Calder, B. J., Philips, L. W., \& Tybout, A. M. (1982). The concept of external validity. Journal of Consumer Research, 9(3), 240-244.

Chatzipanagiotou, K., Veloutsou, C. \& Christodoulides, G. (2016). Decoding the complexity of the consumer-based brand equity process, Journal of Business Research, 69(11), 5479-5486.

Dennis, C., Papagiannidis, S., Alamanos, E., \& Bourlakis, M. (2016). The role of brand attachment strength in higher education. Journal of Business Research, 69(8), 3049-3057.

Eastman, J. K., Goldsmith, R. E., \& Flynn, L. R. (1999). Status consumption in consumer behavior: Scale development and validation. Journal of Marketing Theory and Practice, 7(3), 41-52.

Eelen, J., Özturan, P., \& Verlegh, P. W. J. (2017). The differential impact of brand loyalty on traditional and online word of mouth: The moderating roles of self-brand connection and the desire to help the brand. International Journal of Research in Marketing, 34(4), 872-891.

Ellison, N., Heino, R., \& Gibbs, J. (2006). Managing impressions online: Self-presentation processes in the online dating environment. Journal of Computer Mediated Communication, 11(2), 415-441.

Escalas, J. E. (2004). Narrative processing: Building consumer connections to brands. Journal of Consumer Psychology, 14(1-2), 168-180. 
Escalas, J. E. \& Bettman, J. R. (2003). You are what they eat: The influence of reference groups on consumers' connections to brands. Journal of Consumer Psychology, 13(3), 339-348.

Escalas, J. E. \& Bettman, J. R. (2009). Self-brand connections: The role of reference groups and celebrity endorsers in the creation of brand meaning. In D. J. Maclnnis, C. W. Park, \& J. R. Priester (Eds.), Handbook of brand relationships (pp.107-123). New York: Society for Consumer Psychology and M.E. Sharp.

Ferraro, R., Kirmani, A., \& Matherly, T. (2013). Look at me! Look at me! Conspicuous brand usage, self-brand connection, and dilution. Journal of Marketing Research, 50(4), 477-488.

Goffman, E. (1959). The presentation of self in everyday life. Harmondsworth.

Gretry, A., Horváth, C., Belei, N., \& van Riel, A. C. (2017). "Don't pretend to be my friend!" When an informal brand communication style backfires on social media. Journal of Business Research, 74, 77-89.

Grégoire, Y., \& Fisher, R. J. (2008). Customer betrayal and retaliation: when your best customers become your worst enemies. Journal of the Academy of Marketing Science, 36(2), 247-261.

Grégoire, Y., Tripp, T. M., \& Legoux, R. (2009). When customer love turns into lasting hate: The effects of relationship strength and time on customer revenge and avoidance. Journal of Marketing, 73(6), 18-32.

Hair, J. F., Black, W. C., Babin, B. J., \& Anderson, R. E. (2010). Multivariate data analysis: A global perspective (7th ed.). New Jersey: Prentice Hall.

Jaccard, J. \& Wan C. K. (1996). Lisrel approaches to interaction effect in multiple regression. California: Sage Publications Inc.

Juntunen, M., Juntunen, J., \& Autere, V. (2013). Co-creating nonprofit brand equity. International Journal of Nonprofit and Voluntary Sector Marketing, 18(2), 122-132.

Keller, K. L. (1993). Conceptualizing, measuring, and managing customer-based brand equity. Journal of Marketing, 57(1), 1-22.

Keller, K. L. (2003). Brand synthesis: The multidimensionality of brand knowledge. Journal of Consumer Research, 29(4), 595-600.

Keller, K. L. (2016). Reflections on customer-based brand equity: perspectives, progress, and priorities. AMS Review, 6(1), 1-16. 
Kent, R. J. \& Allen, C. T. (1994). Competitive interference effects in consumer memory for advertising: The role of brand familiarity. Journal of Marketing, 58(July), 97-105.

Koll, O. \& von Wallpach, S. (2014). Intended brand associations: Do they really drive consumer response? Journal of Business Research, 67(7), 1501-1507.

Lam, S. K., Ahearne, M., Mullins, R., Hayati, B., \& Schillewaert, N. (2013). Exploring the dynamics of antecedents to consumer-brand identification with a new brand. Journal of the Academy of Marketing Science, 41(2), 234-252.

Langaro, D., Rita, P., \& de Fátima Salgueiro, M. (2018). Do social networking sites contribute for building brands? Evaluating the impact of users' participation on brand awareness and brand attitude. Journal of Marketing Communications, 24(2), 146-168.

Leary, M. R. \& Kowalski, R. M. (1990). Impression management: A literature review and twocomponent model. Psychological Bulletin, 107(1), 34-47.

Loftus, E. F., \& Loftus, G. R. (1980). On the permanence of stored information in the human brain. American Psychologist, 35(5), 409-420.

MacInnis, D. J. \& Folkes V. S. (2017). Humanizing brands: When brands seem to be like me, part of me, and in a relationship with me. Journal of Consumer Psychology, 27(3), 335-374.

Merchant, A. \& Rose, G. M. (2013). Effects of advertising-evoked vicarious nostalgia on brand heritage. Journal of Business Research, 66(12), 2619-2625.

Mühlbacher, H., Raies, K., Grohs, R. \& Koll, O. (2016). Drivers of brand strength: Configural paths to strong cognitive brand equity, Journal of Business Research, 69(8), 2774-2780.

O’Guinn, T. C., Tanner, R. J., \& Maeng, A. (2015). Turning to space: Social density, social class, and the value of things in stores. Journal of Consumer Research, 42(2), 196-213.

Olson, J. C., \& Jacoby, J. (1972). Cue utilization in the quality perception process. In M. Venkatesan (Vol. Eds.), Advances in consumer research. Vol. 3. Advances in Consumer Research (pp. 167-179). Chicago: Association for Consumer Research.

Park, C. W., MacInnis, D. J., Priester, J., Eisingerich, A. B., \& Iacobucci, D. (2010). Brand attachment and brand attitude strength: Conceptual and empirical differentiation of two critical brand equity drivers. Journal of Marketing, 74(6), 1-17.

Schmitt, B. (2012). The consumer psychology of brands. Journal of Consumer Psychology, 22(1), 7-17. 
Schneider, D. J., Hastorf, A. H., \& Ellsworth, P. (1979). Person perception (2nd ed.). Reading, Massachusetts: Addison-Wesley.

Spassova, G. \& Lee, A. Y. (2013). Looking into the future: A match between self-view and temporal distance. Journal of Consumer Research, 40(1), 159-171.

Swaminathan, V., \& Dommer, S. L. (2012). When is our connection to brands like our connection to people? Differentiating between consumer-brand relationships and interpersonal relationships. In S. Fournier, M. Breazeale, \& M. Fetscherin (Eds.), Consumerbrand relationships: Theory and practice (pp. 30-56). New York: Routledge.

Tan, T. M., Salo, J., Juntunen, J., \& Kumar, A. (2017). The effect of temporal distance on selfpresentation by brand. In A. Gneezy, V. Griskevicius, \& P. Williams (Vol. Eds.), Advances in consumer research. Vol. 45. Advances in Consumer Research (pp. 481-485). Duluth: Association for Consumer Research. 


\section{Fig. 1}

Comparison of structural models amongst basic model, well-liked brand, and new brands
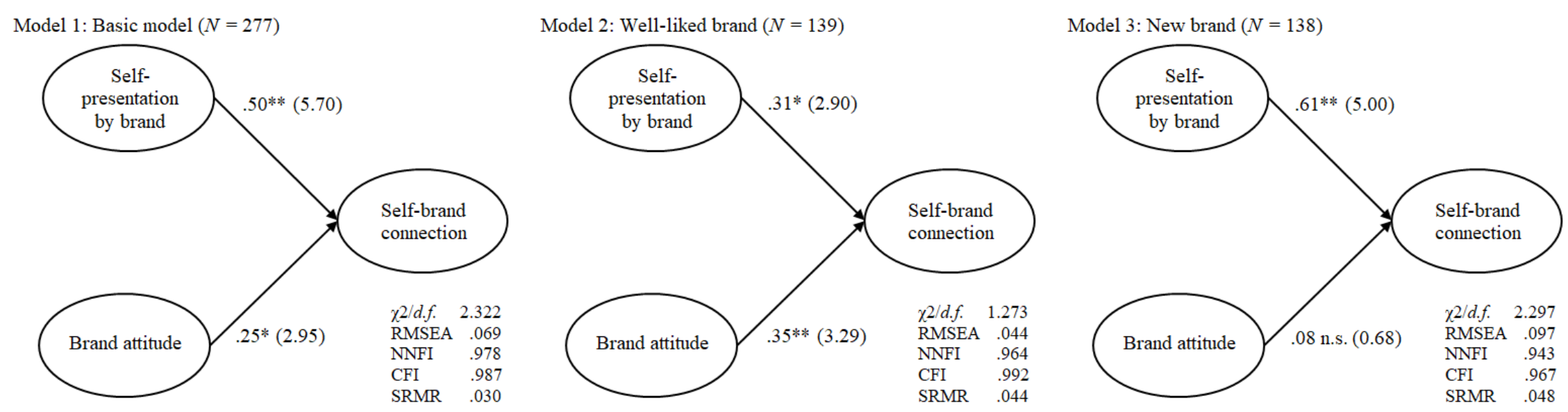

Standardized parameter estimates $(t$ value); $* *=$ Significant at $p<.001 ; *=$ Significant at $p<.05 ;$ n.s. $=$ Not significant 
Fig. 2

Comparison of structural models amongst basic model, well-liked brand, and unfavorable brands
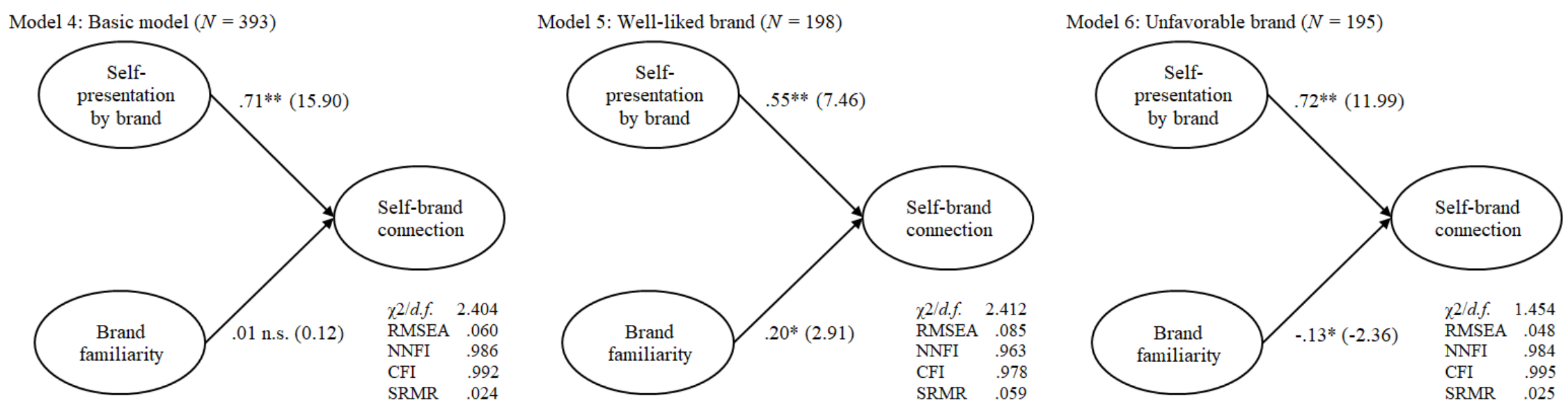

Standardized parameter estimates $(t$ value); $* *=$ Significant at $p<.001 ; *=$ Significant at $p<.05$; n.s. $=$ Not significant 


\section{Table 1}

Demographics of survey respondents

\begin{tabular}{|c|c|c|}
\hline Profile category & $\begin{array}{c}\text { Clothing brands } \\
\text { Study } 1(N)=277\end{array}$ & $\begin{array}{c}\text { Consumer electronics } \\
\text { product brands } \\
\text { Study } 2(N)=393 \\
\end{array}$ \\
\hline \multicolumn{3}{|l|}{ Gender } \\
\hline Male & $47 \%$ & $48 \%$ \\
\hline Female & $53 \%$ & $52 \%$ \\
\hline \multicolumn{3}{|l|}{ Age } \\
\hline Mean & 26.3 years & 35.3 years \\
\hline Standard Deviation & 7.255 & 10.919 \\
\hline \multicolumn{3}{|l|}{ Nationality } \\
\hline Finland & $96 \%$ & $0 \%$ \\
\hline United States & $0 \%$ & $91 \%$ \\
\hline Others & $4 \%$ & $9 \%$ \\
\hline \multicolumn{3}{|l|}{ Level of education } \\
\hline High school graduate & $0 \%$ & $14 \%$ \\
\hline Bachelor degree & $73 \%$ & $73 \%$ \\
\hline Master degree & $24 \%$ & $11 \%$ \\
\hline Professional degree & $2 \%$ & $1 \%$ \\
\hline Doctorate degree & $1 \%$ & $1 \%$ \\
\hline \multicolumn{3}{|l|}{ Employment status* } \\
\hline Employed full time & $16 \%$ & $58 \%$ \\
\hline Employed part time & $14 \%$ & $18 \%$ \\
\hline Unemployed looking for work & $3 \%$ & $9 \%$ \\
\hline Unemployed not looking for work & $1 \%$ & $7 \%$ \\
\hline Retired & $0 \%$ & $2 \%$ \\
\hline Student & $88 \%$ & $6 \%$ \\
\hline
\end{tabular}




\section{Table 2}

Results of standardized factor loading, Cronbach's Alpha, composite reliability, average variance extracted, and model fit indices

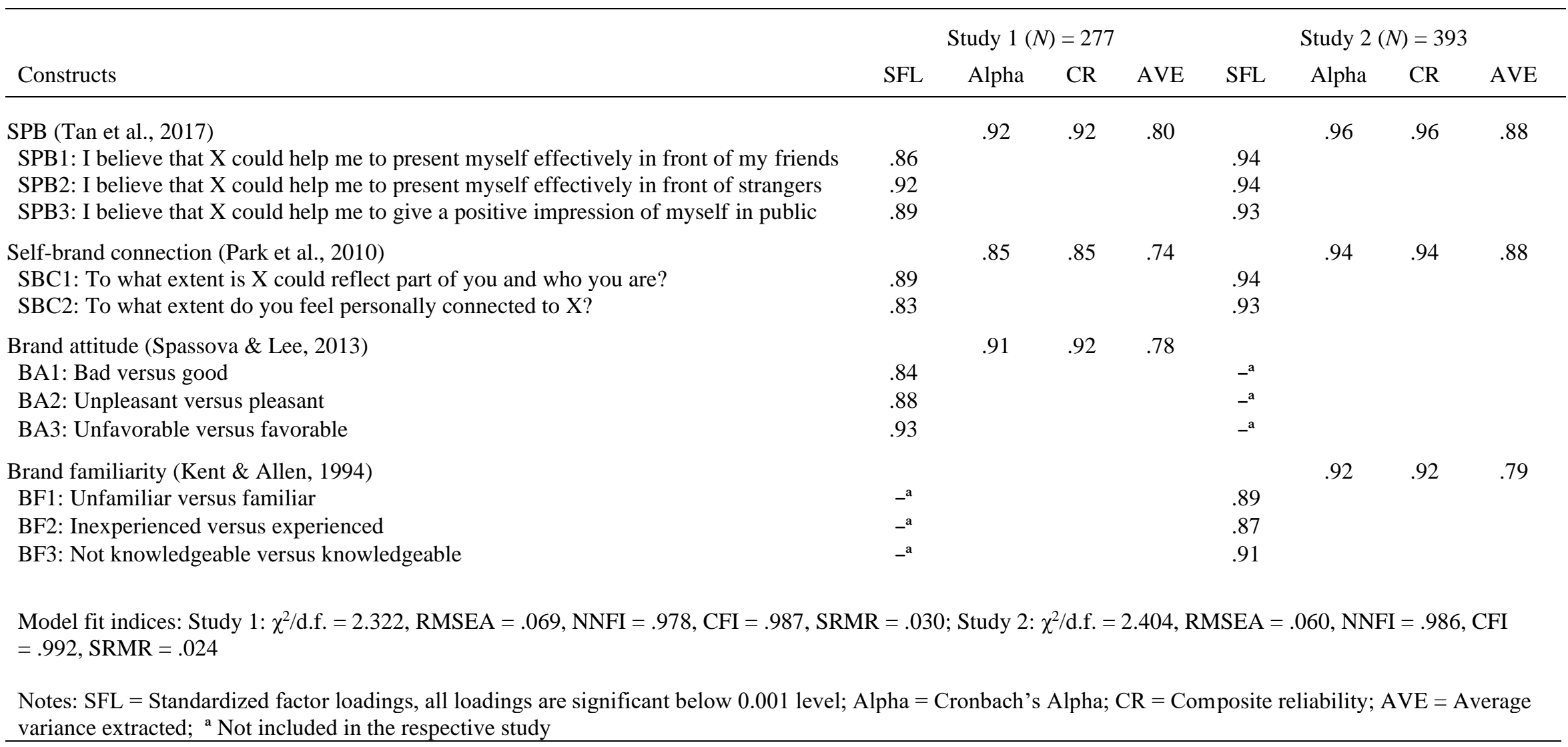




\section{Table 3}

Result of the discriminant validity analysis

\begin{tabular}{|c|c|c|c|c|c|}
\hline Constructs & & 1 & 2 & 3 & 4 \\
\hline \multirow{2}{*}{ 1. SPB } & Study 1 & .893 & & & \\
\hline & Study 2 & .936 & & & \\
\hline \multirow[t]{2}{*}{ 2. Self-brand connection } & Study 1 & $.678 * *$ & .860 & & \\
\hline & Study 2 & $.713 * *$ & .937 & & \\
\hline \multirow[t]{2}{*}{ 3. Brand attitude } & Study 1 & $.730 * *$ & $.611 * *$ & .883 & \\
\hline & Study 2 & $-^{\mathrm{a}}$ & $-^{\mathrm{a}}$ & $-^{a}$ & \\
\hline \multirow[t]{2}{*}{ 4. Brand familiarity } & Study 1 & $-^{\mathrm{a}}$ & $-^{\mathrm{a}}$ & $--^{a}$ & $-^{\mathrm{a}}$ \\
\hline & Study 2 & $.201 * *$ & $.148^{*}$ & $-{ }^{\mathrm{a}}$ & .889 \\
\hline \multicolumn{6}{|c|}{$\begin{array}{l}\text { Notes: } \\
* * \text {. Correlation is significant at the } .001 \text { level ( } 2 \text {-tailed) } \\
\text { *. Correlation is significant at the } .01 \text { level ( } 2 \text {-tailed) } \\
\text { a Not included in the respective study } \\
\text { Square root of AVE in bold }\end{array}$} \\
\hline
\end{tabular}




\section{Table 4}

\section{Summary of results}

\begin{tabular}{|c|c|c|}
\hline Hypotheses & Explanations & Results \\
\hline $\begin{array}{l}\text { H1. SPB is positively related to self-brand } \\
\text { connection }\end{array}$ & $\begin{array}{l}\text { Study } 1 \text { (Model 1): } \beta=.50, t=5.70, p<.001 ; \\
\text { Study } 2 \text { (Model 4): } \beta=.71, t=15.90, p<.001\end{array}$ & Supported \\
\hline $\begin{array}{l}\text { H2. Brand attitude is positively related to self- } \\
\text { brand connection }\end{array}$ & Study $1($ Model 1): $\beta=.25, t=2.95, p=.003$ & Supported \\
\hline $\begin{array}{l}\text { H3. Brand attitude has a stronger positive effect } \\
\text { on self-brand connection than SPB for a well- } \\
\text { liked brand. }\end{array}$ & $\begin{array}{l}\text { Study } 1 \text { well-liked brands (Model 2): Chi- } \\
\text { square difference test of brand attitude } \rightarrow \text { Self- } \\
\text { brand connection and SPB } \rightarrow \text { Self-brand } \\
\text { connection }(\Delta \beta=.04, \Delta \chi 2=10.04, \Delta d . f .=1, p \\
=.002)\end{array}$ & Supported \\
\hline $\begin{array}{l}\text { H4. SPB has a stronger positive effect on self- } \\
\text { brand connection than brand attitude for a new } \\
\text { brand }\end{array}$ & $\begin{array}{l}\text { Study } 1 \text { new brand (Model } 3): \text { SPB } \rightarrow \text { Self- } \\
\text { brand connection }(\beta=.61, t=5.00, p<.001) \text {; } \\
\text { Brand attitude } \rightarrow \text { Self-brand connection }(\beta \\
=.08, t=0.68, p=.504)\end{array}$ & Supported \\
\hline $\begin{array}{l}\text { H5. SPB has a stronger positive effect on self- } \\
\text { brand connection than brand familiarity for a } \\
\text { well-liked brand }\end{array}$ & $\begin{array}{l}\text { Study } 2 \text { chi-square difference test of brand } \\
\text { familiarity } \rightarrow \text { Self-brand connection and SPB } \\
\rightarrow \text { Self-brand connection: Model } 5(\Delta \beta=.35 \text {, } \\
\Delta \chi 2=0.55, \Delta d . f .=1, p=.457) \\
\text { Remark: It is supported as there was } .35 \\
\text { difference in the comparison of parameter } \\
\text { estimates }\end{array}$ & Supported \\
\hline $\begin{array}{l}\text { H6. Brand familiarity is negatively related to } \\
\text { self-brand connection for an unfavorable brand }\end{array}$ & $\begin{array}{l}\text { Study } 2 \text { unfavorable brands (Model 6): Brand } \\
\text { familiarity } \rightarrow \text { Self-brand connection }(\beta=-.13 \text {, } \\
t=-2.36, p=.018)\end{array}$ & Supported \\
\hline
\end{tabular}




\section{Appendix A}

Study 1: Fictitious brand logo and description

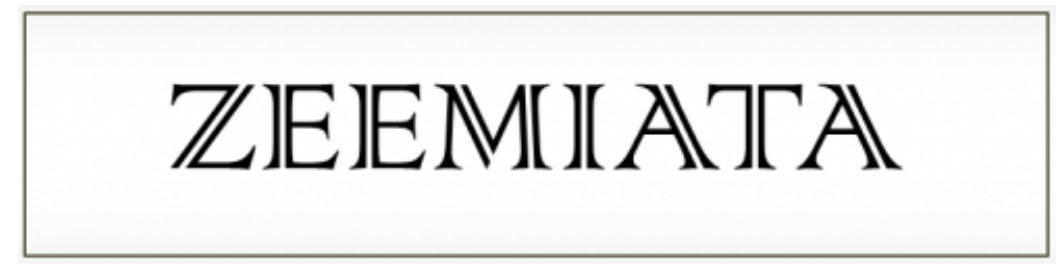

Zeemiata is Japanese unisex wear that focuses on being simple, essential, and universal, so customers can freely match the brand's clothing with their unique styles in any way they choose, every day of the year. Zeemiata was set up by Haruto Zeemiata in 1985 in Tokyo. Haruto is a fashion enthusiast who aims to express individuality and present unique personality through casual wear, a fashion movement that combines elements of countercultures around the world with modern casual style. Since 1985, Zeemiata has continued to aspire toward excellence in quality, design, and technology. Zeemiata is more than just a clothing brand-it is a way of thinking: a steady consciousness of constant change, uniqueness, diversity, and the challenging of conventions. 


\section{Appendix B}

Factor loadings and error variances for each structural model

Model 1: Study 1 Basic Model $(N=277)$

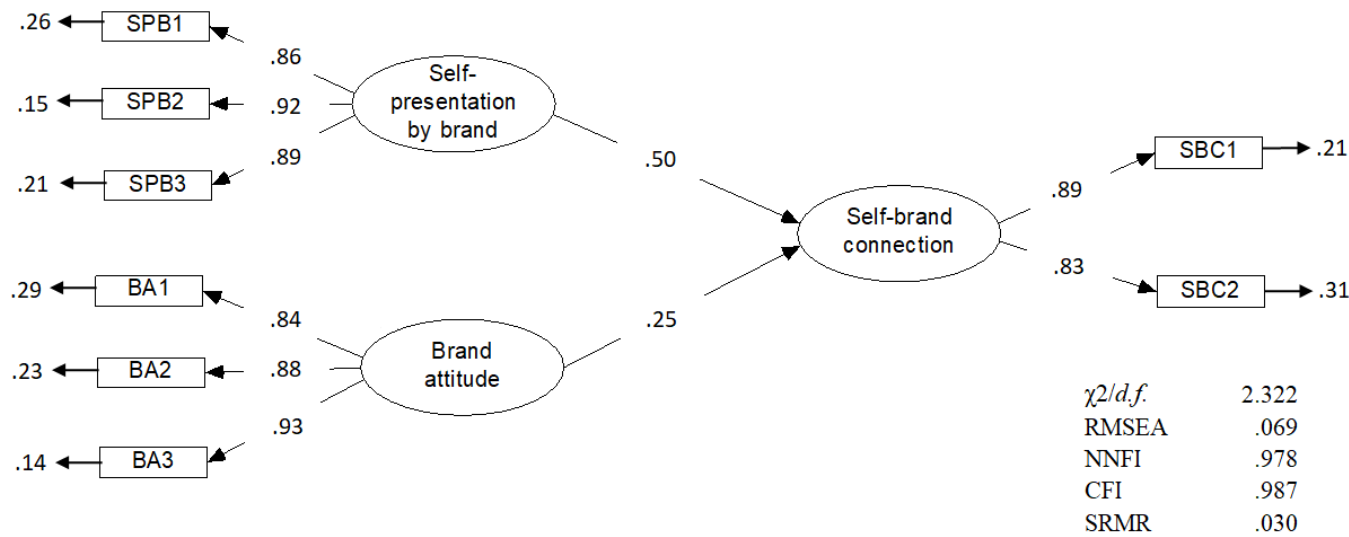

Model 2: Study 1 Well-liked brand $(N=139)$

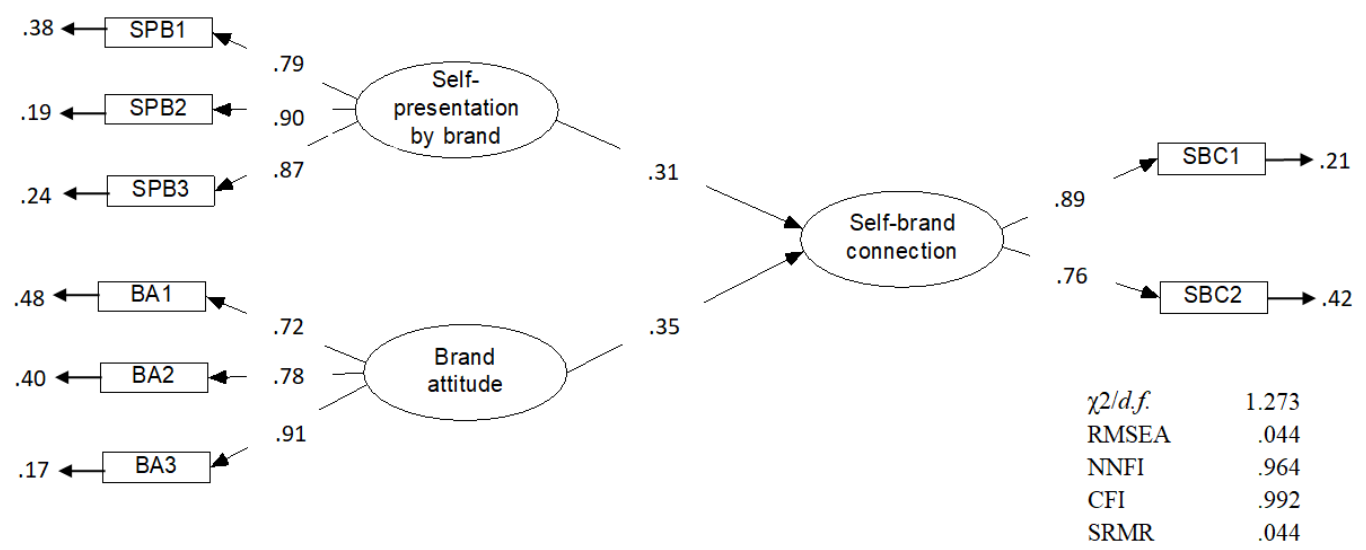

Model 3: Study $1 \mathrm{New}$ brand $(N=138)$

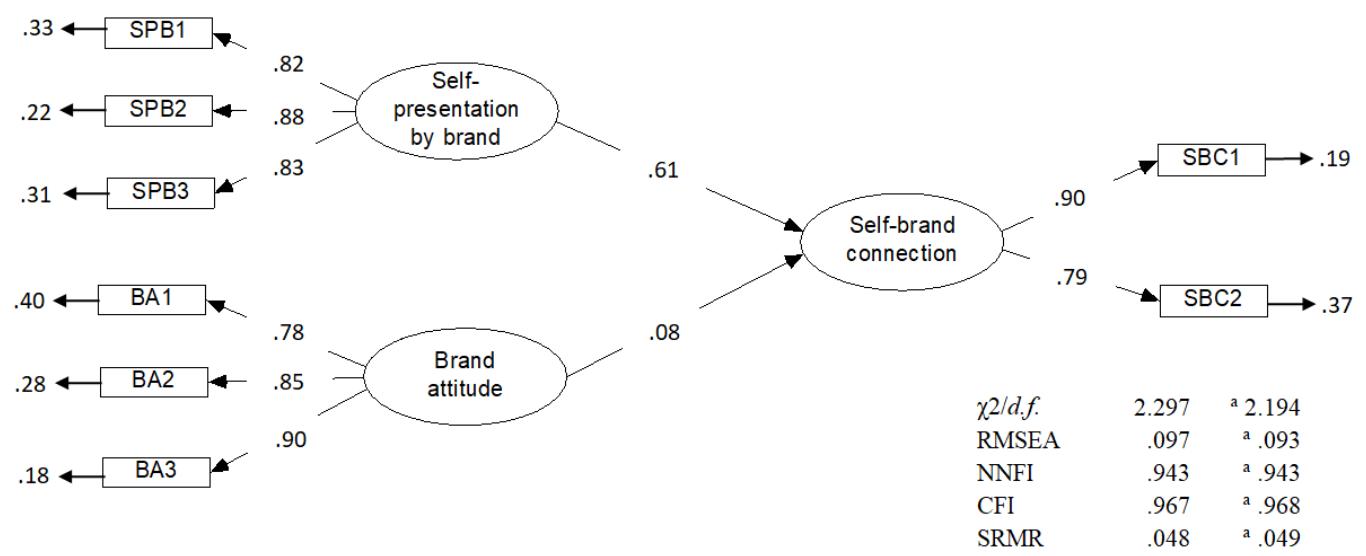

${ }^{a}$ Models without non-significant path coefficient 
Model 4: Study 2 Basic Model $(N=393)$

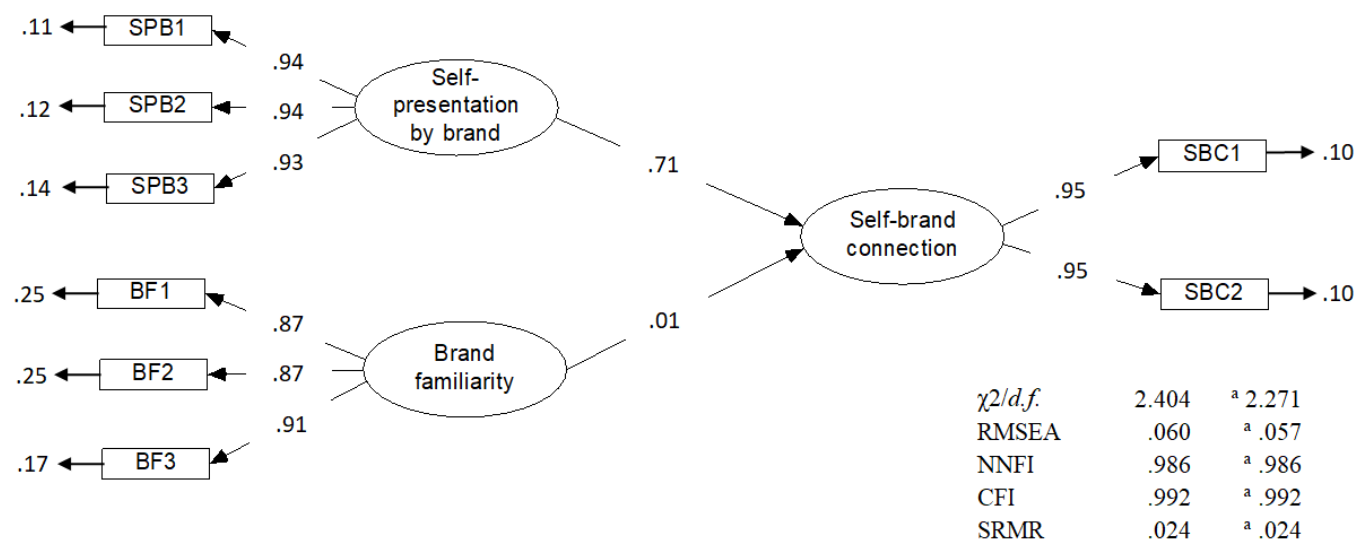

Model 5: Study 2 Well-liked brand $(N=198)$

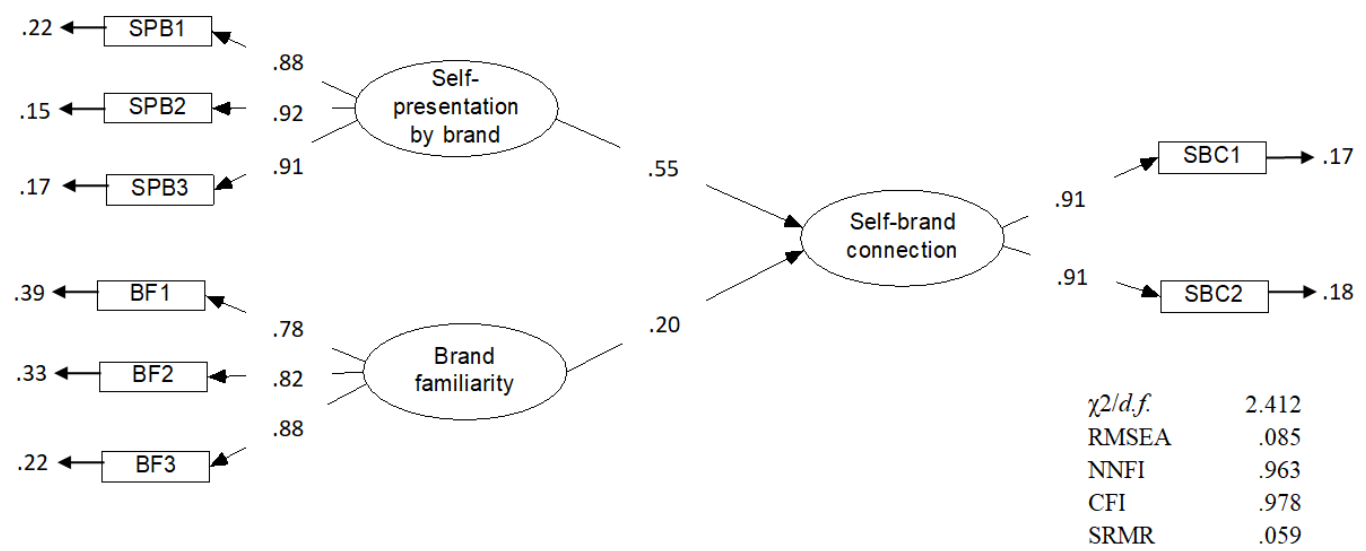

Model 6: Study 2 Unfavorable brand $(N=195)$

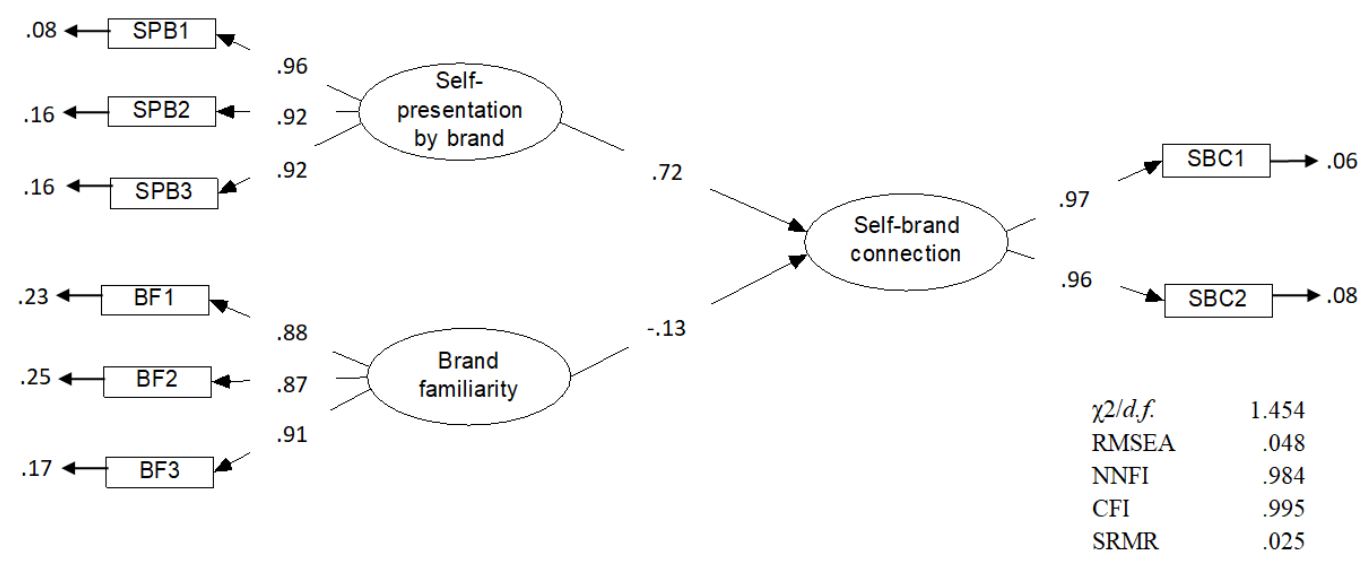

${ }^{\mathrm{a}}$ Models without non-significant path coefficient 


\section{Author Biographies}

Teck Ming Tan, (teckming.tan@ oulu.fi) holds D.Sc. (Marketing) from the University of Oulu, Finland. He is an assistant professor at the Oulu Business School. His research interests include brand equity, self-presentation, self-congruence, construal-level theory, and brand betrayal. His paper has been published in the European Journal of Marketing, Journal of Business Research, Electronic Commerce Research, Journal of Retailing and Consumer Services, and NA-Advances in Consumer Research.

Jari Salo, (jari.salo@helsinki.fi) holds D.Sc. (Econ. \& Bus.Adm.) from the University of Oulu, Oulu Business School (AACSB), Finland. He is Professor of Marketing at the University of Helsinki. He has over 160 scientific publications including books. Research topics include among others digital marketing (including social media and mobile marketing) industrial marketing, branding, consumer behaviour, innovation, commercialization of innovation, sports marketing and project marketing.

Jouni Juntunen, (jouni.juntunen@ oulu.fi) is an Adjunct Professor at the University of Oulu, Faculty of Technology, Finland. He works as an Associate Professor (senior research fellow) in the Department of Marketing, University of Oulu/Oulu Business School, Finland. His research interests include for example machine learning, supply chain management, strategic management, efficient industry structures in logistics service markets, and outsourcing. He also studies logistics issues in cooperating with the Finnish Transport and Logistics Association (SKAL) and The Finnish Defence Forces. His papers have been published for example in the Journal of Business Research and International Journal of Physical Distribution \& Logistics Management.

Ashish Kumar, (ashish.kumar@aalto.fi) is an assistant professor at the Department of Marketing, Aalto University School of Business. His research interests include digital marketing, social media marketing, multichannel retailing and health marketing. He received his $\mathrm{PhD}$ in marketing from the School of Management and an MA in economics from the College of Arts and Sciences, respectively, from the State University of New York at Buffalo. He also has an undergraduate degree in computer science from India. His research has been published in journals such as the Journal of Marketing, Information Systems Research, and Journal of Retailing. 